Reprod. Nutr. Dévelop., 1988, 28 (6 B), 1581-1586.

\title{
Establishment of uteroplacental circulation
}

\author{
R. PIJNENBORG
}

Department of Obstetrics and Gynecology,

U.Z. St. Rafael, Gasthuisberg, B 3000 Leuven, Be/gium.

Summary. Haemochorial placentation, as it occurs in the human and other primate and rodent species, requires a connection of the placenta with supplying maternal (uteroplacental) arteries. Very little is known of the initial stages but endovascular trophoblast invasion seems to represent an essential element for further elaboration of an adequate uteroplacental circulation.

In the human, endovascular trophoblast arrives in myometrial segments of spiral arteries only from about 15 weeks of pregnancy. This is preceded by an interstitial type of cytotrophoblast invasion which seems to be associated with regressive changes in spiral artery walls. It is possible that the latter forms an essential priming factor to allow subsequent endovascular migration.

Endovascular trophoblast invasion has been documented in different laboratory animals, including the rat and the golden hamster. Especially in the latter case a sequence of changes in the maternal component, i.e. the maternal cellular elements in the spiral artery walls, precede the arrival of trophoblast. Besides, there is also some evidence of haemodynamical factor(s) influencing trophoblast migration. Because of the importance of this phenomenon in the establishment of an adequate uteroplacental circulation, it is essential to develop further experimental models for studying pathological situations as exist in human pregnancy.

\section{Introduction.}

An essential aspect ot the establishment of placentation in mammals is the elaboration of an adequate maternal blood supply. Notably in species with haemochorial placentation, the placenta becomes functionally mature only when an intraplacental circulation of maternal blood is started and this requires an efficient connection with the supplying maternal arteries. Very little is known about the way this is achieved.

In the human there is some evidence that the developing conceptus starts to communicate with maternal blood via the superficial endometrial (decidual) capillaries (Hamilton and Boyd, 1960; Harris and Ramsey, 1966). There is a controversy whether these capillaries are tapped or alternatively become incorporated within the primitive syncytial lacunar system. A direct communication with endometrial spiral arteries is thought to be initiated only during the progressive expansion of the cytotrophoblastic shell, when spiral artery walls are breached by the invading trophoblastic cells. 
In experimental animals like the golden hamster and the rat, the chorioallantoic placenta develops from the ectoplacental cone, which represents the earliest organized trophoblastic structure growing into the decidua. Again it is not clear at what point communication with the maternal vascular system takes place. However, the fact that a communication exists from a relatively early stage of pregnancy is indicated by the presence of endovascular trophoblast in endometrial spiral arteries that starts to migrate retrogradely into these vessels. This is a characteristic that both rodent species have in common with the human (and other primate species) (Orsini, 1954 ; Bridgman, 1949 ; Hamilton \& Boyd, 1960). Following their appearance in the arteries, trophoblastic cells have a marked effect on the structure of the artery walls which are thought to be essential to assure an adequate maternal blood supply to the fetus (Brosens et al., 1967).

It is the purpose of this contribution to focus on uteroplacental arterial development in the first trimester of human pregnancy and to compare this with some observations performed in hamsters and rats.

\section{Materials and methods.}

The data on the human were collected from a series of 48 hysterectomy specimens from 8 to 18 weeks of pregnancy, collected by the late Professor H.G. Dixon at the University of Bristol, England. This material had been fixed in $4 \%$ formaldehyde in saline. Slices through the central portion of the placenta and adjacent uterine wall were processed as a whole and embedded in paraffin wax. Details about morphometrical techniques and statistical analysis were published elsewhere (Pijnenborg et al., 1981, 1983).

Placental bed material from hamsters and rats were collected by fixation of placentas in situ, followed by cutting slices through the whole placenta plus uterine wall. Most of the animal material was fixed in Bouin, but some selected specimens were fixed in glutaraldehyde. Embedding in paraffin wax or epon and further processing, i.e. sectioning and staining, was performed by standard methods.

\section{Results and discussion.}

\section{The human.}

From the earliest specimens that we were able to examine, i.e. at 8 weeks of pregnancy, endovascular trophoblast was present in the decidual spiral arteries. It is clear that by that time it is already too late to study the whole sequence of changes in the arteries at that level. Especially in the central part of the placental bed the walls of the spiral arteries consist of an amorphous acidophilic material in which the invading basophilic trophoblastic cells have been embedded. On the other hand, vessels supplying the marginal zones of the intervillous space have a more recognizable arterial structure in the period 8 to 10 weeks of pregnancy. 
Besides the endovascular trophoblast the presence of interstitial cytotrophoblast is a feature of the placental bed. Sometimes this interstitial trophoblast may be clustered around the spiral arteries, but this is not the case in all vessels. In some areas transformation of cytotrophoblast into multinuclear giant cells has begun. Because the lack of suitable material of earlier pregnancy, it was not possible to deduce from our observations a sequence of interactions between different cells (decidual cells, interstitial trophoblast, endovascular trophoblast, endothelial cells, smooth muscle cells), that have lead to the so-called physiological changes in the spiral arteries at the decidua level.

At 8-14 weeks of pregnancy, endovascular trophoblast is never seen in any of the myometrial segments of spiral arteries. On the other hand, interstitial invasion of the myometrium by interstitial cytotrophoblast has just begun. The pattern of this invasion, spreading from the centre in a ringlike fashion to the margin of the placental bed, has been documented by a morphometrical study (Pijnenborg et al., 1981). Very often interstitial trophoblast arrives in the vicinity of spiral arteries. In the latter interesting events can be observed during this same period of pregnancy. The vessel walls do not retain their integrity : the endothelia undergo a marked swelling, the muscular layers loose their normal coherence, while basophilic cells appear in the media. Many of these vessels become so disorganized that it is no longer possible to recognize them as arteries without studying serial sections. The relationship between medial disruption and the presence of interstitial cytotrophoblast could be demonstrated by statistical analysis (Pijnenborg et al., 1983). Only after the drastic degenerative changes have occurred, endovascular trophoblast makes its appearance in the myometrial segments of the spiral arteries. This is the second wave of endovascular trophoblast invasion that starts at about 15 weeks of pregnancy.

We may conclude from these observations that there is a specific time sequence of events in the placental bed : first, interstitial trophoblast arrives in the myometrium, then degenerative changes are seen in the spiral artery walls, and this is followed by the arrival of endovascular trophoblast and subsequent physiological changes. It is tempting to suggest that vascular disruption is actually induced by the presence of interstitial trophoblast, although there is no evidence for a direct lytic action by invading trophoblast. It is not clear by what mechanism the second wave of endovascular trophoblast invasion is triggered. Is it by chemotaxis, for example by substances released from the disrupted vessels, or can haemodynamic changes, that inevitably must follow from the extreme vessel wall disorganization, be responsible ? In fact is would be very important to learn more about the early trophoblast-maternal tissue interactions in order to understand more fully some pathological conditions of pregnancy. For example in pre-eclampsia physiological changes do not occur in myometrial segments of spiral arteries (Brosens et al., 1972) which may be explained by an inhibition of the second wave of endovascular trophoblast invasion (Roberton et al., 1975, 1985). Abnormal development of uteroplacental arteries may be the cause of an impaired placental blood circulation in such condition (Browne \& Veal, 1953). There is no doubt that also other pathological conditions are related to defects in 
uteroplacental arterial development (Khong et al., 1986, 1987 ; Robertson et al., 1981, 1986).

\section{Experimental animals.}

Is it possible to aquire a better knowledge about factors leading to the development of an adequate uteroplacental blood supply by studying laboratory animals ? Endovascular trophoblast invasion has been studied in different rodent and primate species.

Notably in the rat the presence of endovascular trophoblast in decidual tissue had been recognized already in the previous century (Duval, 1891), although its association with the supplying uteroplacental arteries was only clearly documented by Gerard (1927). Detailed cytological studies of that trophoblast at the light optical (Bridgman, 1949) as well as at the electron microscopical level (Legrand, 1969) have been published, but no particular attention has been paid to tissue changes of the maternal component. The actual migration itself was beautifully demonstrated by a ${ }^{3} \mathrm{H}$-thymidine labelling study performed by Legrand (1974), while an involvement of that trophoblast with steroid metabolism was demonstrated by the same group (Legrand \& Nguyen Son Hung, 1972).

Another species that has been studied in some detail is the golden hamster (Orsini, 1954). In this species a well-timed sequence of events occurs in the vessel walls before the arrival of trophoblast, including proliferation of the adventitial elements, decidualization and endometrial granulocyte accumulation. Furthermore, endovascular trophoblast migration coincides with a spontaneous necrosis in the decidualized spiral artery wall (Pijnenborg et al., 1974). It is not easy to link histological changes in uteroplacental arteries with the actual blood supply to the placenta. One rather suggestive observation has been the appearance within the placenta of a «maternal arterial space » in continuity with a spiral artery, which precedes the actual appearance and migration of endovascular trophoblast. This suggests (a) haemodynamical factor(s) in the development of the uteroplacental arteries and their physiological changes. In ovariectomized hamsters with progesterone but not estrogen supplementation it was recognized that some of the decidual spiral arteries did not give rise to the development of an associated maternal arterial space within the placenta. No endovascular trophoblast migration was initiated in such vessels while the decidualized vessel walls underwent necrosis without replacement by trophoblast and physiological changes. These abnormal placentas were not able to sustain fetal development (Pijnenborg et al., 1975).

Endovascular trophoblast has also been studied in different primate species (Ramsey \& Harris, 1966 ; Panigel \& Brun, 1968; Legrand \& Panigel, 1971). Following a comparative study Ramsey et al. (1976) have questioned the existence of a relationship between decidualization on the one hand and the extent of trophoblastic invasion. Further studies of placentation in non-human primates are certainly desirable, although for a number of practical reasons primates are not the first-choice experimental animals. 
Regarding possible pathological events in human pregnancy, there is a need for experimental models to study for example pre-eclampsia or fetal growth retardation. Placentation in the different laboratory rodents, which have a haemochorial type of placentation, is based on the same principles as govern the situation in the human. A major difference however exists in pregnancy duration, and this may remain a decisive factor that precludes the use of for example rats and mice as efficient experimental models for studying defects of uteroplacental circulation with some relevance to the human.

$27^{e}$ Réunion de la Société française pour l'Etude de la Fertilité. Paris, 29, 30 sept., $1^{\text {er }}$ oct. 1988

\section{Résumé. Mise en place de la circulation utéro-placentaire.}

La placentation hémochoriale chez les humains, les primates et certains rongeurs, exige une connection du placenta avec les vaisseaux maternels (utéroplacentaires). Les stades initiaux de ce processus sont mal connus, mais l'invasion du trophoblaste endovasculaire paraît essentiel pour l'élaboration consécutive d'une circulation utéroplacentaire adéquate.

Chez l'homme le trophoblaste endovasculaire envahit les segments myométriaux des artères spiralées à partir seulement de la quinzième semaine gestationnelle. Ceci est précédé d'une invasion de trophoblaste du type interstitiel, associée à des changements régressifs dans les parois des artères spiralées. Ceux-ci peuvent être nécessaires pour permettre la migration endovasculaire subséquente.

L'invasion endovasculaire de trophoblaste a été décrite dans plusieurs animaux de laboratoire, notamment le rat et le hamster doré. C'est surtout chez ce dernier qu'une séquence de modifications des éléments cellulaires maternels (dans les parois de l'artère spiralée) précède l'arrivée des cellules trophoblastiques. En outre, certaines observations soutiennent l'hypothèse de l'existence de facteurs hémodynamiques qui influencent la migration du trophoblaste. $\mathrm{Vu}$ l'importance de ces phénomènes dans le développement d'une perfusion utéroplacentaire adéquate, il nous paraît important de développer de nouveaux modèles expérimentaux pour étudier les situations pathologiques, constatées lors de grossesses humaines.

\section{References}

BRIDGMAN J., 1949. A morphological study of the development of the placenta of the rat. II. An histological and cytological study of the development of the chorio-allantoic placenta of the white rat. J. Morph., 83, 195-224.

BROSENS I., ROBERTSON W. B., DIXON H. G., 1967. The physiological response of the vessels of the placental bed to normal pregnancy. J. Path. Bact., 93, 569-592.

BROSENS I., ROBERTSON W. B., DIXON H. G., 1972. The role of the spiral arteries in the pathogenesis of pre-eclampsia. Obstet. Gynecol. Annu., 1, 177-191.

BROWNE J.C. M., VEALL N., 1953. The maternal placental blood flow in normotensive and hypertensive women. J. Obstet. Gynaec. Brit. Empire, 60, 141-147.

DUVAL M., 1891. Le placenta des rongeurs. III. Le placenta de la souris et du rat. J. Anat. Physiol. (Paris), 27, 515-612.

GÉRARD P., 1927. Contribution à l'étude du placenta maternel des Rongeurs. Arch. Biol., 37. 407-454.

HAMILTON W. J., BOYD J. D., 1960. Development of the human placenta in the first three months of gestation. J. Anat., 94, 297-328. 
HARRIS J.W.S., RAMSEY E. M., 1966. The morphology of human uteroplacental vasculature. Carnegie Contrib. Embryol., 38, 43-58.

KHONG T. Y., DE WOLF F., ROBERTSON W. B., BROSENS I., 1986. Inadequate maternal vascular response to placentation in pregnancies complicated by pre-eclampsia and by small-forgestational age infants. Br. J. Obstet. Gynec., 93, 1049-1059.

KHONG T. Y., LIDDELL H. S., ROBERTSON W. B., 1987. Defective haemochorial placentation as a cause of miscarriage : a preliminary study. Br. J. Obstet. Gynec., 94, 649-655.

LEGRAND C., 1969. Ultrastructure du trophoblaste endovasculaire chez le rat Mus norvicus albinus. C.R. Acad. Sci. Paris, 268, 2095-2097.

LEGRAND C., PANIGEL M., 1971. L'ultrastructure des cellules intravasculaires dans les artères spiralées utéroplacentaires au début de la gestation chez le Babouin, Papio cynocephalus. C.R. Acad. Sci. Paris, 272, 429-432.

LEGRAND C., 1974. Origine et évolution des cellules trophoblastiques intra-artérielles chez le rat : étude autoradiographique. J. Embryol. exp. Morph., 31, 693-705.

LEGRAND C., NGUYEN SON HUNG, 1972. Mise en évidence d'une activité stéroido-déshydrogénasique dans le trophoblaste intra-artériel chez la ratte gestante. C.R. Acad. Sci., 275, 1513-1515.

ORSINI M.W., 1954. The trophoblastic giant cells and endovascular cells, associated with pregnancy in the hamster, Cricetus auratus. Am. J. Anat., 94, 273-330.

PANIGEL M., BRUN J. -L., 1968. Anatomie vasculaire, histologie et ultrastructure du placenta à la fin de la gestation chez certains primates: Macaca (Cynomolgus) irus et Cercopithecus (Erythrocebus) patas. Bull. Assoc. Anat., 142, 1270-1286.

PIJNENBORG R., ROBERTSON W. B., BROSENS I., 1974. The arterial migration of trophoblast in the uterus of the golden hamster (Mesocricetus auratus). J. Reprod. Fert., 40, 269-280.

PIJNENBORG R., ROBERTSON W. B., BROSENS I., 1975. The role of ovarian steroids in placental development and endovascular trophoblast migration in the golden hamster. $J$. Reprod. Fert., 44. 43-51.

PIJNENBORG R., BLAND J. M., ROBERTSON W. B., DIXON G., BROSENS I., 1981. The pattern of interstitial trophoblastic invasion of the myometrium in early human pregnancy. Placenta, 2, 303-316

PIJNENBORG R., BLAND J. M., ROBERTSON W. B., BROSENS I., 1983. Uteroplacental arterial changes related to interstitial trophoblast migration in early human pregnancy. Placenta, 4 , 397-414.

RAMSEY E. M., HARRIS J. W. S., 1966. Comparison of uteroplacental vasculature and circulation in the rhesus monkey and man. Carnegie Contrib. Embryol., 38, 59-70.

RAMSEY E. M., HOUSTON M. L., HARRIS J. W. S., 1976. Interactions of the trophoblast and maternal tissues in three closely related primate species. Am. J. Obstet. Gynecol., 124. $647-652$.

ROBERTSON W. B., BROSENS I., DIXON G., 1975. Uteroplacental vascular pathology. Europ. J. Obstet. Gynec. Reprod. Biol., 5, 47-65.

ROBERTSON W. B., BROSENS I., DIXON H. G., 1981. Maternal blood supply in fetal growth retardation, 126-138. In VAN ASSCHE F. A., ROBERTSON W. B., RENAER M., Fetal growth retardation, Churchill Livingstone, London.

ROBERTSON W. B., BROSENS I., LANDELLS W. N., 1985. Abnormal placentation. Obstet. Gynecol. Annu. 14, 411-426.

ROBERTSON W. B., KHONG T. Y., BROSENS I., DE WOLF F., SHEPPARD B. L., BONNAR J., 1986. The placental bed biopsy: review from three Europan centers. Am. J. Obstet. Gynecol., 155, 401-412. 